\title{
Features of development of Smart Grid networks in communities, modeling methods and challenges in the implementation of intelligent power supply systems
}

\author{
H. Melnychuk \\ Ministry of Development of Communities and Territories of Ukraine, Kyiv, Ukraine \\ Corresponding author.Email: @ melnychuk.gv@gmail.com
}

Paper received 11.12.20; Accepted for publication 22.12.20.

\author{
https://doi.org/10.31174/SEND-NT2020-244VIII30-14
}

Annotation. The article considers the problems of development of power grids with the introduction of intelligent systems of interaction between producers and consumers of electricity based on the SmartGrid approach, requirements for methods of calculating such systems, an example of using an improved method of individual components for modeling, and organizational and other challenges.

Keywords: SmartGrid, power supply, electrical networks, energy management, settlements and territories.

Introduction. New innovative technologies in the fields of alternative energy sources, accumulation and transformation of electric energy, as well as new opportunities for energy management and process modeling, contribute to the formation and development of new approaches to improving energy systems, including intelligent control, distributed electricity generation and horizontal decentralization of power supply networks.

A brief overview of publications on the topic. The formation of power supply networks began more than 100 years ago in settlements, in particular from large cities - initially they were small power plants to provide street lighting and power to tram companies. With the development of industry and electric drive systems, the demand for electricity among factories and plants increased, and domestic electricity markets were gradually formed in cities. Further centralization and formation of national electricity networks took place after the Second World War and ended with the spread of nuclear energy [1].

Centralization of the power grid, along with the benefits, has brought new challenges, including imbalance of consumption within the day. Initially, electricity consumption was quite predictable: during the day - industry, in the evening - lighting, peak loads - during peak hours of electric vehicles. However, due to the growing share of household consumption, peak loads are becoming more pronounced despite the increase in energy efficiency of individual appliances, their number is growing much faster [2].

Electricity is the most controlled and environmentally friendly energy source, it is publicly available, and now there is an increase in the use of electricity continues, we can talk about a new wave of electrification. The key areas for expanding the use of electricity are further electrification in the domestic sector (both in households and in the nonproductive sector of the economy) and in transport, combined with increasing electricity use in critical infrastructures [3].

Electrification in households occurs by replacing the use of other energy sources in the most energy-intensive areas control of the microclimate of the premises (heating and air conditioning), water heating and cooking. More and more modern houses do not have an individual gas supply - all household appliances are powered by electricity. The share of electricity consumption by the population is growing: for example, if in 2002 in Ukraine it was only almost 19\%, in 2011 - already $25.5 \%$, and in 2019 this figure was already about $30 \%$ [4].

Electrification in transport is currently taking place both directly by replacing the use of petrol and diesel engines with electric motors in cars (distribution of electric cars) and indirectly - by increasing the role of public transport and micromobility (bicycles, various types of electric scooters) within the new concept of intercity transportation which called "sustainable mobility". In turn, in the field of public transport are rapidly expanding electric buses and trams, and among the means of micromobility - a variety of electric individual vehicles [5].

The third notable direction of the new wave of electrification is the supply of critical infrastructure. This is the biggest challenge for the power system, because due to further informatization and the introduction of intelligent control systems necessitates an uninterrupted reliable power supply for their operation. In particular, these are the systems that ensure the viability of settlements, such as water supply, sewerage, gas supply, medical facilities, especially specialized hospitals with complex medical equipment, operating complexes, intensive care units, signaling systems for rail and road transport, air traffic control, subway, elevators of highrise buildings, public safety systems. This necessitated a new look at the problem of sustainability of energy supply systems, when there is a significant number of critical consumers of different levels of priority [1].

These challenges, together with the proliferation of renewable energy sources and the emergence of electricity storage technologies, have led to the concept of Smart Grid an intelligent power supply network that includes both consumers and producers of electricity, takes into account the storage and recovery of electricity by users. systems and remote control on the principle of "Internet of Things". Currently, the Smart Grid approach is one of the basic components of the Smart City concept - intelligent management of urban infrastructure to achieve sustainable development goals $[6,7]$.

Goal. The introduction of intelligent power management systems necessitates the calculation, modeling and forecasting of processes, as power devices are not always able to instantly change the parameters of their work. This, in turn, necessitates the introduction of effective control algorithms for more flexible control of local Smart Grid power systems. For this purpose the most suitable analytical methods which, unlike numerical, allow to carry out the analysis of a nonlinear chain in the general kind, instead of for certain values of parameters of elements of the schemes.

Materials and methods. Improving the efficiency of local systems with generators and converters of electric energy, solving problems of electromagnetic compatibility of system elements (eliminating their mutual influence), taking into account external influences and special modes of opera- 
tion requires optimization procedures and using of system approaches in modeling processes in these systems.

Graphical, analytical and numerical methods, as well as combined methods are used for the analysis of electrical circuits. Numerical methods have a significant disadvantage, which is that the obtained solution corresponds to a specific case, for which specific parameter values and initial conditions are given. Analytical methods allow to obtain greater accuracy of calculations, although they require a large number of mathematical operations. The solutions in the application of analytical methods are approximate, but their accuracy depends on the detail of the approximation of real characteristics using the basic modeling functions.

The solutions obtained in the analytical form allow to carry out the qualitative analysis of the phenomena occurring in an electric circuit, and also to carry out the further analytical processing: harmonic analysis, finding of maxima and minima, integral indicators, form coefficients, harmonics, other quantitative and qualitative characteristics, the research of behavior when changing parameters.

Table 1. Types of basic functions for Laplace transforms

\begin{tabular}{|c|c|c|c|}
\hline Type & $\begin{array}{c}\text { Name of basic } \\
\text { function }\end{array}$ & Time domain $f_{b, i}(t)$ & $f_{1}(t)=A$ \\
\hline 1 & Level function & $F_{1}(t)=\frac{A}{p}$ \\
\hline 2 & $\begin{array}{c}\text { Sinusoidal } \\
\text { function }\end{array}$ & $f_{2}(t)=\sin \omega t$ & $F_{2}(t)=\frac{\omega}{p^{2}+\omega^{2}}$ \\
\hline 3 & $\begin{array}{c}\text { Exponential } \\
\text { function }\end{array}$ & $f_{3}(t)=e^{-\sigma t}(t)$ & $F_{3}(t)=\frac{1}{p+\alpha}$ \\
\hline 4 & $\begin{array}{c}\text { Direct propor- } \\
\text { tionality } \\
\text { function }\end{array}$ & $f_{4}(t)=A t$ & $F_{4}(t)=\frac{A}{p^{2}}$ \\
\hline
\end{tabular}

Analytical methods are based on the analytical integration of differential equations that describe the state of a nonlinear chain using analytical expressions of the characteristics of nonlinear elements. As an example of an analytical method for calculating processes in electric circuits, consider the method of individual components using Laplace transforms. The vast majority of complex periodic functions that describe the modes of operation of electricity generators can be formed from elementary mathematical functions, which are called basic (Table 1). However, the approximation of the nonlinear characteristic that underlies these methods, leads to the introduction of more or less error in the calculations.

The general approach to the construction of Laplace sdomain for complex periodic functions in the case of a constant duration of integration intervals is considered in detail in [8]. The s-domain $F_{p}(p)$ of the signal function $U(t)$ for the case of rectangular pulses of amplitude $U_{i}$ has the form:

$$
F_{p}(p)=\frac{1}{p} \frac{\left(1-e^{-p T}\right)}{\left(1-e^{-p T_{T}}\right)} \sum_{i=1}^{n} U_{i} e^{-(i-1) p T} .
$$

When the approximation intervals of the function have different durations, ie $\boldsymbol{T}_{\boldsymbol{i}}=\mathrm{v}$ ar, which is a more general case, the s-domain of the signal function is as follows:

$$
F_{p}(p)=\frac{1}{p} \frac{1}{\left(1-e^{-p T_{T}}\right)} \sum_{i=1}^{n} U_{i}\left(e^{-p T_{(i-1)}}-e^{-p T_{i}}\right),
$$

provided that $T_{T}=\sum_{i=1}^{n} T_{i}, T_{0}=0$.

The calculations according to (2) are more complicated in comparison with (1), but in some cases the implementation of the approximation of the generator signal function can simplify the calculations by reducing the number of approximation intervals by combining intervals with the same amplitudes of step pulses.

When constructing modulated functions and signal functions, for the approximation of which it is necessary to apply several basic functions, it is necessary to use the alternation of the basic function with a pause to form a complex basic function. In this case, $T_{i}+T_{\mathrm{O} i}=T_{T}$, where $T_{i}$ is the duration of the basic function, $T_{0 i}-$ is the duration of the pause, wiith $F_{i}(\mathrm{O}+t)=F_{i}\left(T_{i}+T_{\mathrm{O} i}+t\right)$. Then the sdomain of the signal function has the form:

$$
F_{p}(p)=\frac{1}{p} \frac{\left(1-e^{-p T}\right)}{\left(1-e^{-p T_{n}}\right)} \sum_{i=1}^{n} U_{i} e^{-2(i-1) p T} .
$$

The shift of the whole function is carried out by the delay theorem by multiplying by $e^{-p T}$. When approximating several basic functions, it is necessary to comply with the requirements: $\quad F_{i}\left(f_{e i}, T_{i}\right) \cap F_{j}\left(f_{e j}, T_{j}\right)=\varnothing$, where $i \neq j$ and $i, j \in\{1, \ldots, n\}$, ie the requirements of unambiguous definition of the image of the function on the interval.

The sequence of calculations for finding generalized expressions for calculating processes in circles with cyclically variable parameters is as follows:

1) formation of graphs or tables of dependences of cyclic changes of parameters of an electric circuit on time, in the same scale, definition of functions of the generator $U_{G}(t)$ and loading $Z(t)$;

2) formation of s-domain of generator functions $U(p)$ and load $Z(p)$ using Laplace transforms: $U(p)=L\left\{U_{G}(t)\right\}, Z(p)=L\{Z(t)\}$;

3 ) formation of s-domain of current functions in accordance with Ohm's law in operator form: $U(p)=L\left\{U_{G}(t)\right\}$, $Z(p)=L\{Z(t)\}$;

4) finding the original currents using the inverse Laplace transform $I(t)=L^{-1}\{I(p)\}$.

Obtaining current functions at intervals in analytical form allows for accurate calculations to assess current characteristics, optimal choice of parameters of electronic and electrical devices, it is necessary to determine a number of characteristics and coefficients, including operating and average currents, amplitude maxima and minima, shape coefficients, amplitude pulsations value, pulsations according to the current value, pulsations according to the average value, amplitude [9].

In turn, this makes it possible to model and predict the operation of a complex power supply system of the community with several power generators and complex loads, both to optimize the current operation of such a system and to improve and plan development.

Results and discussion. A prerequisite for the use of intelligent power supply systems can be called "smart meters", which began to be introduced by energy companies in the 1980s. The first level of their application was monitoring of 
electricity consumption depending on time, the second consumption management. The most well-known way to manage consumption is different tariffs depending on the time of day when electricity is cheaper at night. However, it fully works in combination with the appropriate equipment for consumers - for example, "smart" sockets and systems that turn on and off devices depending on time, need, load level [10].

Together, such devices and systems are combined into "smart homes". If they also have their own sources of electricity generation (solar panels, wind turbines) or devices for storing electricity (stationary batteries or electric cars with the ability to give electricity to the grid (Vehicle to Grid technology) - then such complexes are called MicroGrid. Smart Grid, it is possible to coordinate the operation of many devices for smoothing peak loads, such "smart" networks MicroGrid have become widespread in the United States, China, Italy and other countries.

At the same time, the introduction of the energy component within the Smart City concept is possible when not only technological and informational solutions for modernization of energy systems are implemented, but also administrative and financial mechanisms for the formation of the local energy market. Such approaches are not only in line with the current vision of Sustainable Development Goals of United Nations Organization and the reduction of the carbon footprint, but also to increase the resilience of infrastructure to external influences.

Conclusions. The introduction of the intelligence networks SmartGrid as one of the key components of the SmartCity concept, when intelligent management of not only information but also energy flows is implemented, forms an interactive electricity market with many consumers, producers and energy storages. This significantly affects the quality of life of residents, and opportunities for business activity, and to improve the environmental situation, makes the community a full participant in the regional and national energy market, but also requires new approaches to regulation, tariffs and billing systems.

At the same time, it requires a rethinking of the principles of building control algorithms for such systems, in particular the involvement of artificial intelligence technologies, which requires appropriate capabilities to predict the behavior of a complex energy system. It is appropriate to use analytical methods for calculating processes in energy systems, which allows to form analytical expressions about the energy characteristics of electricity, analyze external influences and perform process forecasting.

\section{ЛИТЕРАТУРА}

1. Denysiuk S., Melnychuk H. Decentralization of city energy supply systems in the conditions of technological transformations and formation of intellectual cities (smart city) // Scientific foundations of modern engineerinf. Monograph, Boston (USA), 2020 P. 181-204.

2. Техника в её историческом развитии. Отв. ред. С.В. Шухардин, Н.К. Ламан, А.С. Федоров. М.: «Наука». Т.2, 1982. 416 c.

3. Бушуев В.В., Ливинский П.А. Энергоэффективный мегаполис - Smart City «Новая Москва» // Москва: ИД «Энергия», 2015. $76 \mathrm{c.}$

4. Про основні показники роботи паливно-енергетичного комплексу України за 2019 рік «Енергоінформ» № 577 Інформаційно-аналітичне дослідження стану паливноенергетичного комплексу HTCEУ // URL: https://www.ntseu.net.ua/docs/review577-202001.pdf (дата обращения 20.02.2020).

5. Мельничук Г.В. Енергоменеджмент населених пунктів та територій на основі інтелектуальних систем керування електроживленням. Енергетика: економіка, технології, екологія. 2019. № 4 C.76-86

6. Денисюк С.П. Технологічні орієнтири реалізації концепції Smart Grid в електроенергетичних системах // Енергетика: економіка, технології, екологія. 2014. № 1. С. 7-21.

7. National Energy Technology Laboratory. NETL Modern Grid Initiative - Powering Our 21st-Century Economy. United States Department of Energy Office of Electricity Delivery and Energy Reliability, 2007. August. P.17.

8. Денисюк С.П., Мельничук Г.В. Побудова перетворення Лапласа при аналізі електромагнітних процесів у колах 3 циклічно змінюваними параметрами // Електроніка і зв'язок. Київ. 2005. №26. С.29-36.

9. Денисюк С.П., Мельничук Г.В., Колесник П.С. Аналіз інтегральних характеристик систем електроживлення з циклічно змінними параметрами // Праці Ін-ту електродинаміки НАН України: Зб. наук. пр. К.: ІЕД НАНУ, 2011.№28. С.30-35.

10. Кириленко О. В., С. П. Денисюк. Сучасні тенденції побудови та керування режимами електроенергетичних мереж // Энергосбережение. Энергетика. Энергоаудит. 2014. № 9. Спец. вып. Т. 2 : Силовая электроника и энергоэффективность. С. 82-94.

\section{REFERENCES}

2. Shukhardin S.V., Laman N.K., Fedorov A.S. Technology in its historical development // Moscow: "Science". - P. 1, Vol.2, 1982. - 416 p.

3. Bushuev V.V., Livinsky P.A. Energy-efficient metropolis - Smart City "New Moscow" // Moscow: ID "Energy", 2015. - 76 p.

4. On the main indicators of the fuel and energy complex of Ukraine for 2019 "Energoinform" № 577 Information and analytical study of the state of the fuel and energy complex NTSEU // URL: https://www.ntseu.net.ua/docs/review577-202001.pdf (access date 20.02.2020).

5. Melnychuk H. Energy management of settlements and territories on the basis of intelligent power management systems // Energy: economics, technology, ecology, 2019, № 4, P.76-86.

6. Denisyuk S. Technological guidelines for the implementation of the Smart Grid concept in power systems // Energy: economics, technology, ecology, 2014, № 1, P. 7-21.

8. Denisyuk S., Melnichuk H. Formation of Laplace transform in the analysis of electromagnetic processes in circuits with cyclically variable parameters // Electronics and communication, 2005, № 26, P. 29-36.

9. Denisyuk S., Melnichuk H., Kolesnik P. Analysis of integrated characteristics of power supply systems with cyclically variable parameters // Proceedings of the Institute of Electrodynamics of the NAS of Ukraine, IED NASU, 2011, № 28, P. 30-35.

10. Kirilenko O., Denisyuk S. Modern tendencies of construction and management of modes of electric power networks // Energy saving. Energy. Energy audit, 2014, № 9. Special issue Vol. 2: Power electronics and energy efficiency, P. 82-94. 